\title{
POT BUNGA UNTUK MENINGKATKAN PENGETAHUAN AKAR PANGKAT TIGA PADA SISWA KELAS VI SD
}

\author{
Dwi Wahyuni \\ SDN Karangtengah Baru \\ dwiwahyuni2@yahoo.com
}

\begin{abstract}
Abstrak
Tujuan penelitian ini adalah untuk meningkatkan pengetahuan akar pangkat tiga dengan menggunakan gambar pot bunga pada siswa kelas VI SDN Karangtengah Baru. Penelitian ini merupakan penelitian tindakan kelas (PTK), yang terdiri dari dua siklus. Setiap siklus meliputi kegiatan : perencanaan, tindakan, observasi, dan refleksi. Subyek penelitian adalah 28 siswa. Teknik pengumpulan data yang digunakan adalah teknik observasi, catatan lapangan, tes, angket, observasi, dokumentasi. Catatan lapangan digunakan untuk mengetahui aktivitas guru dan siswa dalam pembelajaran. Tes digunakan untuk mengetahui pengetahuan siswa, dan angket untuk mengetahui respon siswa terhadap pembelajaran akar pangkat tiga pada bilangan kubik menggunakan gambar pot bunga. Hasil penelitian menunjukkan bahwa penggunaan gambar pot bunga meningkatkan pengetahuan akar pangkat tiga bilangan kubik. Semua kriteria keberhasilan yang ditetapkan dalam penelitian telah tercapai, diantaranya (1) hasil tes menunjukkan peningkatan nilai rata-rata kelas; (2) persentase siswa yang mencapai nilai $\mathrm{KKm}$ yang ditetapkan meningkat; (3) respon siswa terhadap pembelajaran akar pangkat tiga pada bilangan kubik dengan gambar pot bunga dalam kategori baik.
\end{abstract}

Kata kunci: Pot bunga, akar pangkat tiga, siswa kelas VI

\section{PENDAHULUAN}

Mata pelajaran matematika merupakan salah satu mata pelajaran yang harus diajarkan di semua jenjang pendidikan, baik dari tingkat sekolah dasar (SD) hingga perguruan tinggi. Mata pelajaran matematika tidak hanya bermakna mengenal angka-angka tetapi lebih dari itu mempunyai makna memahami dan menerapkan dalam kehidupan sehari-hari.

Menurut Hudoyo (1980) matematika adalah berkenaan dengan ide-ide abstrak yang tersusun secara hirarkis dan penalaran deduktif. Matematika sering diferensi sebagai suatu kemampuan sistem dimana masing-masing sistem mempunyai sistem tersendiri dan bersifat deduktif aksiomatik. 
Berdasarkan uraian di atas tentang persoalan pembelajaran di kelas, hasil pengamatan, dan studi dokumentasi terhadap siswa kelas VI pada semester 1 tahun pelajaran 2018-2019 menunjukkan siswa masih banyak mengalami kesulitan dalam memahami pelajaran matematika. Berbagai hasil dari pengamatan yang telah dilakukan pada siswa kelas VI ketika diberikan soal-soal yang berkaitan dengan materi matematika akar pangkat tiga kurang berhasil, ini karena siswa kurang semangat, dan sering bosan dalam pembelajaran yang kurang disenangi. Untuk itu pembelajaran perlu digunakan metode maupun alat peraga yang sesuai untuk menarik siswa lebih aktif, kreatif, dan timbul rasa senang sehingga dapat meningkatkan belajar siswa kelas VI pada mata pelajaran matematika. Menurut Suparno, dkk (2001) siswa yang aktif dalam proses pembelajaran dicirikan oleh kedua aktivitas, yaitu aktivitas dalam berfikir (mindson), dan aktivitas dalam berbuat (hands-on). Dengan demikian proses siswa aktif dalam pembelajaran merupakan kegiatan yang harus dilaksanakan secara terus menerus dan tiada henti.

Menurut Piaget yang dikutip oleh Santrock (2012: 329) menyatakan bahwa tahap operasional konkrit berlangsung pada usia 7 sampai denganusia 11 tahun. Siswa SD berada dalam tahapan operasional konkrit, yaitu siswa memerlukan benda konkrit atau permodelan untuk membantu memahami materi. Jadi pembelajaran di SD efektif dilakukan menggunakan benda riil atau gambar untuk menjelaskan materi yang diajarkan. Berdasarkan teori dan kenyataan tersebut di atas, pot bunga dapat diterapkan untuk pembelajaran akar pangkat tiga.

Model gambar pot bunga mempunyai keunggulan, yaitu menarik perhatian siswa pada materi yang sedang dipelajari. Pembelajaran menjadi lebih menarik, terbukti siswa asyik menerapkan akar pangkat tiga menggunakan media gambar pot bunga.

Tujuan dari penelitian: 1) meningkatkan pengetahuan siswa dalam memahami akar pangkat tiga; 2) meningkatkan persentase Ketuntasan Minimal (KKM). Sebagai indikasi bahwa tujuan penelitian tercapai dan berhasil adalah Minimal 75\% siswa mencapai KKM. Skor rata-rata ulangan minimal 75. 
Ruang lingkup pembelajaran matematika di SD meliputi bilangan, geometri, dan pengukuran, serta pengolahan data. Muatan mata pelajaran matematika diberikan di SD mulai dari kelas 1 sampai dengan kelas 6 secara bertahap dari mudah ke sukar, konkret menuju abstrak, dan selanjutnya diarahkan untuk mencapai tujuan pembelajaran matematika.

Anak-anak usia sekolah dasar berada pada tahap operasional konkret. Pada rentang usia tersebut anak mulai menunjukkan perilaku belajar sebagai berikut: 1) mulai memandang dunia secara objektif, bergeser dari satu aspek situasi ke aspek lain secara relektif dan memandang unsur-unsur secara serentak; 2) mulai berpikir secara operasional; 3) mempergunakan berpikir operasional untuk mengklasifikasikan benda-benda; 4) membentuk dan mempergunakan keterhubungan aturan-aturan, prinsip ilmiah sederhana, dan mempergunakan hubungan sebab akibat; dan 5) memahami konsep substansi, volume zat cair,panjang, lebar, luas, dan berat.

Belajar bermakna (meaningfully learning) merupakan suatu proses dikaitkannya informasi baru oada konsep konseprelevan yang terdapat dalam struktur kognitif seseorang. Kebermaknaan belajar sebagai hasil dari peristiwa mengajar ditandai oleh terjadinya hubungan antara aspek-aspek, konsep-konsep, informasi atau situasi baru dengan komponen-komponen yang relevan di dalam struktur kognitif siswa.

Proses belajar tidak sekadar menghafal konsep-konsep atau fakta-fakta belaka, tetapi merupakan kegiatan menghubungkan konsep-konsep untuk menghasilkan pemahaman yang utuh, sehingga konsep yang dipelajari dipahami secara baik dan tidak mudah dilupakan. Supaya terjadi belajar bermakna maka guru harus berusaha mengetahui dan menggali konsep-konsep yang telah dimiliki siswa dan membantu memadukannya secara harmonis konsep-konsep tersebut dengan pengetahuan baru yang akan diajarkan.

Feldmand (2012: 214) menyatakan bahwa tahap operasional konkret (Piaget) terjadi antara usia 7-12 tahun ditandai dengan aktif dan tepatnya anak dalam menggunakan logika. Pemikiran operasional konkret berlaku juga pada operasi logis untuk masalah gagasan. 
Memperhatikan tahapan perkembangan berpikir tersebut, kecenderungan belajar anak usia sekolah dasar kelas VI memiliki tiga ciri, yaitu: 1) konkret, yang mengandung makna proses belajar beranjak dari hal-hal yang konkret yakni yang dapat dilihat, didengar, dibaui, diraba, dan diotak-atik, dengan titik penekanan pada pemanfaatan lingkungan sebagai sumber belajar. Pemanfaatan lingkungan akan menghasilkan proses dan hasil belajar yang lebih bermakna dan bernilai, sebab siswa dihadapkan dengan peristiwa dengan keadaan yang sebenarnya, keadaan yang alami, sehingga lebih nyata, lebih faktual, lebih bermakna, kebenarannya lebih dapat dipertanggungjawabkan; 2) Integratif, dimana tahap usia siswa sekolah dasar memandang sesuatu yang dipelajari sebagai suatu keutuhan, siswa belum mampu memilah-milah konsep dari disiplin ilmu, hal ini melukiskan cara berpikir anak yang deduktif yakni hal umum ke bagian demi bagian; 3) Hierarkis, dimana pada tahap ini usia sekolah dasar, cara siswa belajar secarabertahap mulai dari hal-hal yang sederhana ke hal-hal yang lebih kompleks. Sehubungan dengan hal tersebut, maka perlu diperhatikan mengenai urutan logis, keterkaitan antarmateri, dan cakupan keluasan serta kedalaman materi.

Matematika diajarkan di sekolah untuk menumbuh kembangkan kemampuan agar dapat menerapkannya dalam pengetahuan lain maupun dalam kehidupan sehari-hari. Siswa mempelajari matematika diharapkan dapat memahami prosedur, konsep, memecahkan masalah, produktif dalam bekerja baik secara individu ataupun kelompok.

Bilangan kubik adalah suatu bilangan yang diperoleh dari hasil perkalian tripel (tiga bilangan yang sama, dikalikan), dalam bahasa matematika dinyatakan dengan pangkat tiga $\left(\ldots^{3}\right)$. pangkat tiga itulah yang disebut kubik.

Pangkat tiga dalam matematika (aritmatika dan aljabar) adalah hasil perkalian suatu bilangan $\mathrm{n}$ dua kali berturut-turut dengan dirinya sendiri, atau dikatakan mengalami pemangkatan tiga kali : $\mathrm{n}^{3}=\mathrm{n} \times \mathrm{n} \times \mathrm{n}$.

Operasi Hitung Akar Pangkat Tiga

Pengertian Akar Pangkat Tiga

Rumus $\sqrt[3]{a}=\mathrm{d}$

D disebut bilangan akar kubik ( Subai'ah, 2014:62) 
Menghitung akar kubik adalah teknik berhitung yang sangat mudah. Bahkan kita dapat menjadikannya sebagai permainan matematika yang menyenangkan, contoh:

$63 \times 63=3.969$

Kalikan lagi dengan bilangan semula, yaitu 63.

$3969 \times 63=250.047$

Sekarang kita buktikan bahwa $\sqrt[3]{250.047}=63$

Pertama kita perhatikan menghitung kubik dari dua bilangan yang terdiri dari dua angka. Tiga angka dari belakang untuk mencari satuan, sisanya untuk mencari puluhan. 6 adalah puluhan dan 3 adalah satuan. Bilangan kubik 250.047 dikelompokkan menjadi: 1) 250 untuk mencari puluhan (6), 2) 047 untuk mencari satuan (3). Analisisnya : 6 × 6 × $6=216$, sedangkan 7 × 7 × $7=343$. Maka 250 dihasilkan oleh puluhan 6 .

$3 \times 3 \times 3=27$, satuannya 7, maka 047 pasti dihasilkan oleh satuan 3. Jadi, kita peroleh $\sqrt[3]{250.047}=63$.

Agar lebih mudah menarik akar kubik, sebaiknya siswa paham dan hafal kubik dasar dari 0 sampai dengan 10. Khususnya bagian satuan yang perlu mendapat perhatian khusus (Nggermanto, 2014: 73-75).

Untuk mencari $\sqrt[3]{\ldots}$ dengan cepat, perhatikan :

Angka satuan, lihatlah pasangan bilangan di bawah. Angka puluhan, ambil yang paling mendekati.

Tabel Pangkat Tiga Bilangan $0-9$

Pasangan Bilangan

1. $0^{3}=0 \times 0 \times 0=0$

$0 \leftrightarrow 0$

2. $1^{3}=1 \times 1 \times 1=1$

$1 \leftrightarrow 1$

3. $2^{3}=2 \times 2 \times 2=8$

$2 \leftrightarrow 8$

4. $3^{3}=3 \times 3 \times 3=27$

$3 \leftrightarrow 7$

5. $4^{3}=4 \times 4 \times 4=64$

$4 \leftrightarrow 4$

$6.5^{3}=5 \times 5 \times 5=125$

$5 \leftrightarrow 5$

7. $6^{3}=6 \times 6 \times 6=216$

$6 \leftrightarrow 6$

8. $7^{3}=7 \times 7 \times 7=343$

$7 \leftrightarrow 3$

9. $8^{3}=8 \times 8 \times 8=512$

$8 \leftrightarrow 2$ 


\section{Pot Bunga}

Pot adalah tempat yang terbuat dari tanah, semen, plastik dan lain sebagainya, berguna untuk menanam tanaman bunga. Gambar pot bunga terdiri dari pot, satu tangkai bunga dan dua daun.

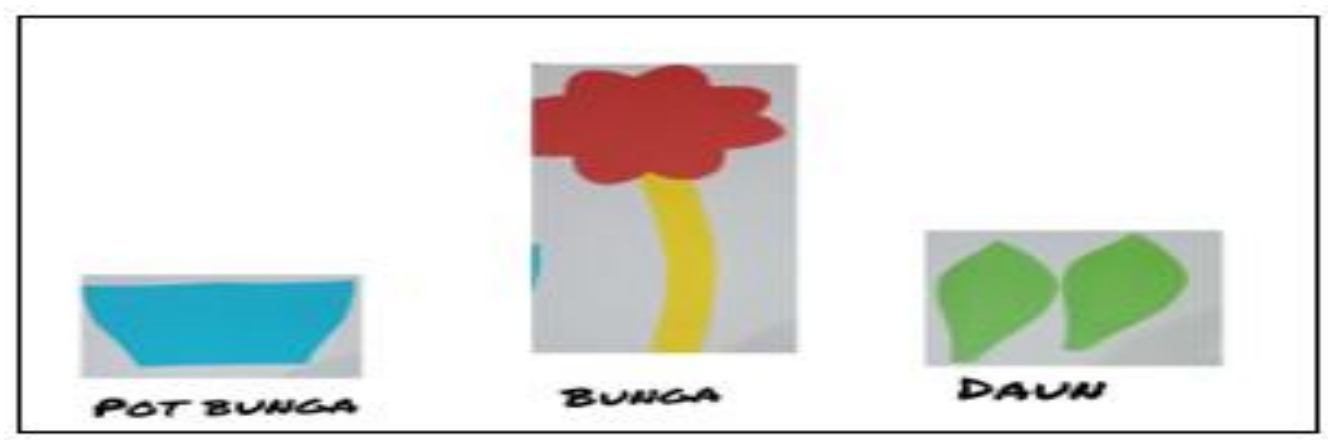

Gambar 1. Pot Bunga, Bunga, dan Daun

Untuk pelajaran akar pangkat tiga suatu bilangan kubik menggunakan media gambar pot bunga bertujuan supaya pembelajaran lebih menarik sehingga minat siswa pada materi pelajaran menjadi lebih meningkat. Materi akar pangkat tiga suatu bilangan kubik dapat dikuasai siswa dengan baik.

Gambar bunga sudah diberi angka suatu bilangan kubik, daun sebelah kanan digunakan menulis hasil satuan, dan daun sebelah kiri merupakan hasil puluhan. Hasil puluhan dan satuan digabung menjadi hasil penarikan akar pangkat tiga yang ditulis pada gambar pot bunga.

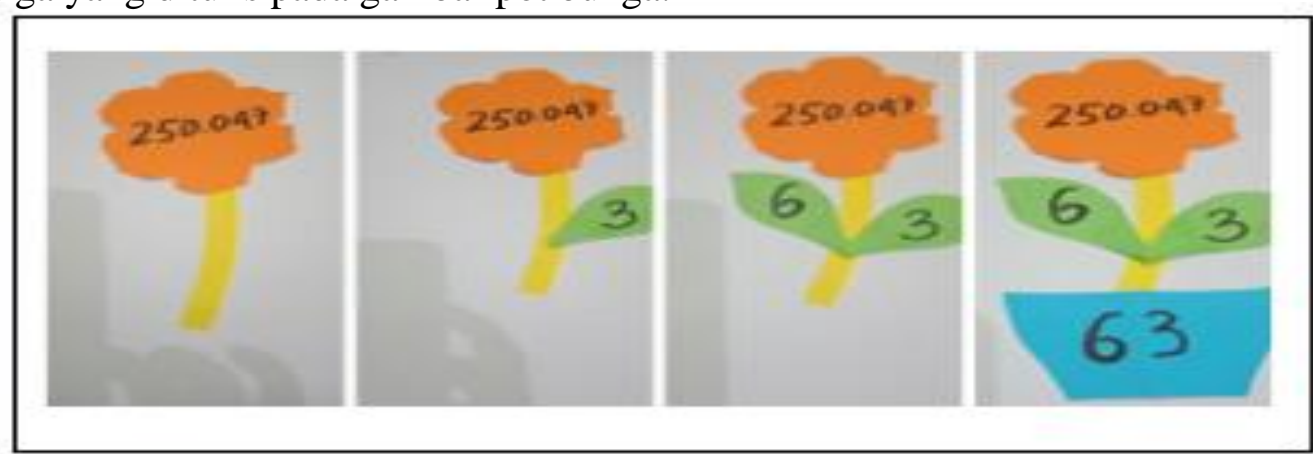

Gambar 2. Pot Bunga Penarikan Akar Pangkat Tiga 


\section{METODE}

Berdasarkan pengamatan pembelajaran di kelas VI, diperoleh hasil sebagai berikut: 1) Guru mengajarkan materi akar pangkat tiga suatu bilangan kubik dengan cara konvensional, yaitu menulis di papan tulis tanpa media pembelajaran; 2) Proses pembelajaran belum mendapatkan hasil sesuai KKM; 3) Siswa kurang tertarik karena materinya abstrak.

Berdasarkan hasil tersebut, disusun rencana penelitian tindakan untuk memperbaiki materi pelajaran penarikan akar pangkat tiga suatu bilangan kubik. Hasil penyusunan tersebut sebagai berikut: 1) tersusunnya jadwal pelaksanaan tindakan siklus I; 2) tersusunnya Rencana Pelaksanaan Pembelajaran (RPP) tentang materi yang diajarkan dan digunakan dalam tindakan; 3) tersedianya media yang akan digunakan dalam pembelajaran akar pangkat tiga suatu bilangan kubik dengan model Pot Bunga; 4) Tersusunya Lembar kegiatan Siswa (LKS) yang digunakan dlam pembelajaran; 5) Tersusunnya kisi-kisi soal tes setelah tindakan siklus dan lembar soal tes setelah tindakan siklus 1 ; 6) tersusunnya angket respon siswa yang diberikan pada akhir siklus 1 ; 7) tersusunnya lembar observasi yang digunakan untuk mengetahui secara langsung pelaksanaan pembelajaran materi akar pangkat tiga suatu bilangan kubik.

Untuk mengetahui kemampuan awal siswa dilakukan tes. Menurut Arikunto (2006: 150), tes merupakan serentetan pertanyaan atau latihan serta alat lain yang digunakan untuk mengukur ketrampilan, pengetahuan, intelegensi, kumpulan atau bakat yang dimiliki oleh individu atau kelompok. Dalam penelitian ini, bentuk tes yang digunakan adalah tipe soal uraian. Bentuk uraian dipilih karena dipandang dapat memberikan indikasi yang baik untuk mengukur sejauh mana pemahaman siswa terhadap materi pelajaran yang didapatkan.

Hasil analisis tes menunjukkan bahwa nilai rata-rata peserta didik kelas VI A SDN Karangtengah Baru masih rendah yaitu sebesar 72,86\%. Baru 15 dari 28 peserta didik yang memenuhi KKM yang ditetapkan yaitu 75 atau sebesar 53,57 yang mencapai ketuntasan, seperti yang terlihat pada Tabel 1. 
Tabel 1. Perolehan Nilai Tes Awal

\begin{tabular}{lc}
\hline \multicolumn{1}{c}{ Keterangan } & Nilai \\
\hline Nilai tertinggi & 100 \\
Nilai terendah & 40 \\
Rata-rata nilai & 72,86 \\
Presentase siswa belajar tuntas & 53,57 \\
\hline
\end{tabular}

Tabel 2. Persentase Hasil Pengamatan Aktivitas Guru

\begin{tabular}{llllllll}
\hline & \multicolumn{3}{c}{ Hasil Pengamatan } & \multicolumn{3}{c}{ Hasil Pengamatan } \\
\hline \multicolumn{3}{c}{ Pertemuan II } & \multicolumn{4}{c}{ Pertemuan II } \\
Observer 1 & \multicolumn{2}{c}{ Observer 2 } & \multicolumn{2}{c}{ Observer 1 } & \multicolumn{2}{c}{ Observer 2 } \\
Skor & Persentase & Skor & Persentase & Skor & Persentase & Skor & Persentase \\
19 & $86,36 \%$ & 19 & $86,36 \%$ & 22 & $100 \%$ & 22 & $100 \%$ \\
\hline
\end{tabular}

Berdasarkan Tabel 1, dilaksanakan tindakan menggunakan model pot bunga untuk meningkatkan pengetahuan akar pangkat tiga suatu bilangan kubik. model pot bunga belum pernah digunakan di SDN Karangtengah Baru sehingga penting untuk mengetahui respon siswa dan guru kelas VI A, serta menjelaskan tujuan dari penelitian.

\section{HASIL DAN PEMBAHASAN}

\section{Hasil Penelitian Tindakan Siklus 1}

Berdasarkan catatan selama penelitian siklus 1, guru mengawali kegiatan dengan memotivasi siswa dan menjelaskan tujuan dari pembelajaran dan kegiatan yang harus dilakukan.

Siswa dan guru tampak antusias dalam pembelajaran. Beberapa siswa mulai mengajukan pertanyaan dan mencoba maju mengerjakan beberapa soal sehingga waktu yang dialokasikan bertambah. Pertemuan kedua soal yang dipraktekkan dibatasi supaya waktu yang digunakan efesien.

Kegiatan dilanjutkan mengerjakan LKS dalam kelompok. Ketika peserta didik mengerjakan soal dalam LKS guru berkeliling untuk memberikan bimbingan. Setelah soal selesai dikerjakan dilanjutka presentasi kelompok. Akhir penelitian dilakukan evaluasi. 
Hasil pengamatan yang diperoleh dari isisan lembar observasi pada kegiatan guru untuk siklus 1 terlihat pada Tabel 2. Berdasarkan pertemuan I siklus 1, dari 22 indikator yang diamati ada 3 indikator yang belum terlaksana. Diantaranya indikator 13 tentang guru membimbing siswa menarik kesimpulan, indikator 18 tentang guru melaksanakan pembelajaran sesuai dengan alokasi waktu yang direncanakan, dan indikator 19 tentang guru melakukan refleksi atau merangkum dengan melibatkan siswa sehingga skor rata-rata presentasi baru mencapai $86,3 \%$.

Tabel 3. Hasil Pengamatan Siswa

\begin{tabular}{cccc}
\hline \multicolumn{4}{c}{ Hasil Pengamatan } \\
\hline & \multicolumn{2}{c}{ Pertemuan I } \\
Skor & Pbserver 1 & Skor & Observer 2 \\
\hline 8 & $88,88 \%$ & 8 & Presentase \\
\hline
\end{tabular}

Tabel 4. Nilai Tes Sesudah Tindakan Siklus 1

\begin{tabular}{lc}
\hline \multicolumn{1}{c}{ Keterangan } & Nilai \\
\hline Nilai tertinggi & 100 \\
Nilai terendah & 40 \\
Rata-rata nilai & 85 \\
\hline Persentase siswa belajar tuntas & 67.85 \\
\hline
\end{tabular}

Pada pertemuan 2, dari 22 indikator yang diamati hanya 1 indikator yang belum terlaksana yaitu indikator 19 tentang guru melakukan refleksi atau merangkum dengan melibatkan siswa sehingga skor rata-rata presentasi baru mencapai 95,45\%. Guru seharusnya melakukan refleksi di setiap akhir pembelajaran. Hal ini dapat membantu siswa merenungkan hal-hal yang sudah dipahami untuk selanjutnya dikembangkan. Begitu pula ada materi yang belum dikuasai dilakukan pengajaran remedial. Hasil pengamatan aktivitas siswa dapat dicermati pada Tabel 3 .

Pada pertemuan I, indikator yang diamati yaitu indikator 5 tentang siswa saling membantu antar anggota dalam kelompok. Pada pertemuan ini sekitar $60 \%$ 
siswa saling membantu dalam kelompok, sedangkan pada pertemuan 2 semua siswa saling membantu antara anggota dalam kelompok sudah muncul.

Hasil tes setelah tindakan siklus 1 nilai rata-rata siswa mencapai 85,00 sedangkan persentase ketuntasan siswa mencapai 67,85\%. Nilai tertinggi 100 dan nilai terendah 40 seperti terlihat pada Tabel 4 .

Refleksi dilakukan oleh peneliti bersama kolaborator setelah pembelajaran siklus 1 berakhir. Hasil rata-rata setelah tindakan siklus 1 mencapai 85,00. Hal ini menunjukkan peningkatan dari hasil tes sebelumya.

Siswa yang mencapai ketuntasan belajar berjumlah 19 dari 28 siswa, atau mencapai $67,85 \%$. Hasil tes setelah tindakan 1, sudah mengalami peningkatan dari tes sebelum tindakan yang hanya mencapai 53,57\%. Namun demikian hasil ini belum memenuhi kriteria keberhasilan yang ditetapkan yaitu $70 \%$ siswa mencapai KKM sebesar 75.

Tabel 5. Observasi Aktivitas Guru Siklus 2

\section{Hasil pengamatan}

\section{Siklus 2}

Observer 1

Observer 2

\begin{tabular}{cccc} 
Skor & Presentase & Skor & Presentase \\
\hline 21 & $95,45 \%$ & 21 & $95,45 \%$ \\
\hline
\end{tabular}

Tabel 6. Observasi Aktivitas Siswa Siklus 2

\begin{tabular}{cccc}
\hline \multicolumn{4}{c}{ Hasil pengamatan } \\
\hline & \multicolumn{3}{c}{ Siklus 2 } \\
Skor & Presentase & Skor & Observer 2 \\
\hline 9 & $100 \%$ & 9 & Presentase \\
\hline
\end{tabular}

Tabel 7. Observasi Tes Prestasi Siswa Siklus 2

\begin{tabular}{lc}
\hline \multicolumn{1}{c}{ Keterangan } & Nilai \\
\hline Nilai tertinggi & 100 \\
Nilai terendah & 75 \\
Rata-rata nilai & 91,79 \\
\hline
\end{tabular}


Persentase siswa belajar tuntas $100 \%$

\section{Hasil Penelitian Tindakan Siklus 2}

Berdasarkan catatan lapangan pada siklus 1 tahap perencanaan mendapatkan hasil tersusunnya RPP dan LKS suklus 2. Pada siklus 2 juga dilakkan pengamatan aktivitas guru seperti pada Tabel 5.

Berdasarkan Tabel 6 aktivitas siswa sudah fokus pada pembelajaran. Halini dibuktikan dengan semua unsur dalam lembar observasi mendapat skor 9. Mata pelajaran mudah dipahami siswa karena perhatian siswa tidak kemana-mana dan tidak saling menganggu.

Selajutnya dilakukan tes prestasi. Hasil tes prestasi siklus 2 dapat dicermati pada Tabel 7

Hasil tes akhir setelah tindakan pada siklus 2 menunjukkan peningkatan pada nilai rata-rata, nilai rata-rata terendah, dan persentase siswa yang mencapai KKM.

Begitu respon siswa mengalami peningkatan seperti terlihat pada siklus 1 mencapai $92,85 \%$ meningkat menjadi $100 \%$ pada siklus 2. Keberhasilan pada siklus 2 segnifikan dengan kriteria penelitian sehingga peneliti memutuskan untuk menghentikan penelitian tersebut. Hasil dari pengamatan siklus 1 dan siklus 2, siswa antusias dan senang menggunakan media gambar pot bunga.

\section{Pembahasan}

Hasil penelitian menjawab pertanyaan penelitian sehingga memenuhi semua kriteria keberhasilan dari penelitian. Berdasarkan deskripsi pelaksanaan tindakan siklus 1 dan siklus 2 yang telah menggunakan media gambar pot bunga hasilnya meningkat.

Secara umum nilai rata-rata kelas mengalami peningkatan. Peningkatan nilai rata-rata tes sebelum tindakan mencapai 72,86 , tes setelah tindakan siklus 1 meningkat menjadi 85, dan setelah tindakan siklus 2 mencapai rata-rata 91,79.

Berdasarkan pengamatan siklus 1 guru belum membimbing siswa menarik kesimpulan. Kerja sama dalam kelompok belum optimal sehingga tutor sebaya 
belum dapat berjalan sebagai mana mestinya. Siklus 2 kerja sama dalam kelompok sudah meingkat.

Pada ketercapaian KKM persentase siswa yang mencapai kriteria ketuntasan minimal dari siklus 1 dan siklus 2 mengalami peningkatan. Hal ini membuktikan media gambar pot bunga efektif digunakan dalam pembelajaran akar pangkat tiga suatu bilangan kubik.

Hal ini sejalan dengan penelitian yang dilakukan oleh Trima (2012) yang menyatakan bahwa alat peraga meningkatkan ketrampilan operasi hitung bilangan bulat dalam hal kecepatan dan ketepatan.

Respon peserta didik dari siklus 1 dan siklus 2 dalam kategori baik. Anak menjadi aktif melakukan penghitungan akar pangkat tiga,hal demikian sesuai dengan yang dikemukakan Felmand (2012) dimana siswa sekolah dasar dalamtahap operasional konkrit (Piaget)

Suatu proses pembelajaran dapat dikatakan baik apabila melibatkan proses berpikir. Dengan demikian siswa menggunakan kemampuan kognitif/ intelektualnya. Dalam belajar matematika, siswa perlu menggunakan kemampuan kognitif tersebut untuk belajar konsep-konsep dan struktur-struktur matematika serta mencari hubungan antara keduanya.

Abstraknya materi pelajaran matematika seharusnya memotivasi guru untuk melakukan inovasi. Guru yang aktif dan kreatif melakukan inovasi pasti disenangi oleh siswanya. Hal ini disebabkan pembelajaran menjadi menarik dan menyenangkan untuk diikuti dan dipelajari. Siswa senang dan mudah menerima pelajaran.

Pada keterlaksanaan pembelajaran, selama proses penelitian dilaksanakan selama 3 hari. Setiap pertemuan selama 2 jam pelajaran. Saat penelitian terbagi ke dalam 2 siklus. Siklus 2 persentase ketercapaian mencapai 88,9\% dari 9 indikator yang diamati. Penggunaan media juga mempengaruhi penyelesaian soal. Hal ini sesuai pendapat Suparno (2001: 69) yang menyatakan operasi logis itu bersifat revelsibel, artinya dapat dimengerti dala dua arah.

Namun begitu penelitian ini juga memiliki beberapa keterbatasan, diantaranya: 1) beberapa siswa tidak mengikuti rangkaian tindakan. 
Sebagianmurid asyik sendiri berbicara dengan teman kelompoknya. Hal demikian perlu didampingi oleh guru supaya akhirnya aktif seperti teman lainnya dalam pembelajaran; 2) materi menentukan akar pangkat tiga suatu bilangan kubik tidak bisa terwakili dengan media gambar pot bunga.

\section{SIMPULAN}

Berdasarkan hasil penelitian dan pembahasan, diambil kesimpulan sebagai berikut: 1) media pot bunga dapat meningkatkan nilai rata-rata siswa kelas VI. Hal ini dikarenakan media pot bunga dapat merangsang anak mencari akar pangkat tiga suatu bilangan kubik; 2) media pot bunga meningkatkan persentasi ketuntasan siswa. Jika semua siswa tuntas dalam belajar dan minimal sama dengan $\mathrm{KKm}$ yang ditetapkan maka tugas guru selanjutnya adalah meningkatkan persentase ketutansannya; 3 ) media pot bunga mendapatkan respon yang baik dari siswa. Anak SD tentu senang belajar dengan media riil sebelum belajar dan berpikir abstrak. Media gambar pot bunga disenangi karena membantu siswa belajar akar pangkat tiga suatu bilangan kubik menjadi menarik.

\section{DAFTAR PUSTAKA}

Arikunto, S. (2006). Prosedur Penelitian Suatu Pendekatan Praktek (Rev.ed.VI). Yogyakarta: Rineka Cipta.

Felmand, R.S. (2012). Discovery The Life Span( $2^{\text {nd }}$ ed). Amherst, Massacusetts: Pearson Prenice Hall

Hudoyo, H. (1980). Strategi Mengajar Belajar Matematika. Jakarta: Depdikbud Dirjen Dikti Proyek Pengembangan Lembaga Pendidikan Tenaga Kependidikan.

Nggermanto. (2014). Permainan Matematika Lingkaan Milenium Paman. Apiq Bandung: Graha Mulia Utama

Santrock, J.W. (2012). Teori Perkembangan Kognitif Jean Piage. Yogyakarta: Kanisius

Subai'ah. (2014). Cara Win Wi Solution Selesaikan Soal Matematika SD Kelas $I V, V, V I$. Yogyakarta: Pustaka Widyatama.

Suparno, P.,Rohandi, R., Sukadi, G., Kartono, S. (2001). Reformasi Pendidikan Sebuah Rekomendasi. Yogyakarta : Penerbit Kanisius.

Trima, M. (2012). Upaya meningkatkan Ketrampilan Operasi Hitung Bilangan Bulat melalui Alat Peraga pada Siswa Kelas IV SD Negeri Mentel I 
Hargosari Tanjungsari Gunungkidul. http://qprint,uny.ac.id5908. Diakses pada tanggal 13 April 2015 